\title{
Erratum to: One pot synthesis, antimicrobial and antioxidant activities of fused uracils: pyrimidodiazepines, lumazines, triazolouracil and xanthines
}

\author{
Samar A. El-Kalyoubi ${ }^{1,2^{*}}$, Eman A. Fayed ${ }^{1}$ and Ahmed S. Abdel-Razek ${ }^{3}$
}

\section{Erratum to: Chemistry Central Journal (2017) 11:66 DOI 10.1186/s13065-017-0294-0}

After the publication of this work [1] it was noticed that the author's name was spelt incorrectly. The author's name should be spelt as: Ahmed S. Abdel-Razek.

The original article was corrected.

\section{Author details}

${ }^{1}$ Department of Pharmaceutical Organic Chemistry, Faculty of Pharmacy (Girls), Al-Azhar University, Nasr City, Cairo 11651, Egypt. ${ }^{2}$ Medical Chemistry Department, Faculty of Medicine (Female Section), Jazan University, Jazan 45142, Saudi Arabia. ${ }^{3}$ Department of Microbial Chemistry, Genetic Engineering and Biotechnology Division, National Research Centre, El-Buhouth St., Dokki-Cairo 12622, Egypt.

The online version of the original article can be found under doi:10.1186/s13065-017-0294-0.

\section{Publisher's Note}

Springer Nature remains neutral with regard to jurisdictional claims in published maps and institutional affiliations.

Received: 26 July 2017 Accepted: 26 July 2017

Published online: 01 August 2017

\section{Reference}

1. El-Kalyoubi SA, Fayed EA, Abdel-Razek AS (2017) One pot synthesis, antimicrobial and antioxidant activities of fused uracils: pyrimidodiazepines, lumazines, triazolouracil and xanthines. Chem Cent J 11:66. doi:10.1186/ s13065-017-0294-0

\footnotetext{
*Correspondence: s.elkalyoubi@hotmail.com

1 Department of Pharmaceutical Organic Chemistry, Faculty of Pharmacy

(Girls), Al-Azhar University, Nasr City, Cairo 11651, Egypt

Full list of author information is available at the end of the article
} provided you give appropriate credit to the original author(s) and the source, provide a link to the Creative Commons license, and indicate if changes were made. The Creative Commons Public Domain Dedication waiver (http://creativecommons.org/ publicdomain/zero/1.0//) applies to the data made available in this article, unless otherwise stated. 